\title{
Grand challenges in marine conservation and sustainable
}

\section{use}

\author{
Annette C. Broderick* \\ Centre for Ecology and Conservation, College of Life and Environmental Sciences, University of Exeter, Cornwall Campus, Penryn, UK \\ ${ }^{*}$ Correspondence: a.c.broderick@exeter.ac.uk
}

Edited and reviewed by:

E. Christien Michael Parsons, George Mason University, USA

Sara M. Maxwell, Stanford University, USA

Keywords: marine conservation, sustainable use, grand challenges, IUCN Red List, biodiversity

The oceans contain the most biologically diverse ecosystems on earth, yet in comparison to terrestrial systems, our understanding and protection of these habitats and their species is lagging (Hendriks et al., 2006; Richardson and Poloczanska, 2008; Polidoro et al., 2009; McCauley et al., 2015). Given the critical ecosystem services that the oceans provide, such as food security, coastal defense, and climate regulation, and with much of the oceans considered overexploited and potentially beyond recovery (Neubauer et al., 2013; Dulvy et al., 2014; Selig et al., 2014), protecting and sustainably using the ocean's resources is a major issue for human well-being. Nearly all of the drivers of biodiversity loss are anthropogenic, and with all studied marine ecosystems affected by human influence (Halpern et al., 2008; Butchart et al., 2010), reducing the threats to marine systems should be within our control. Yet the pressures from human population growth are set to rise and that further exploitation of the ocean's resources will occur is without a doubt. The overarching grand challenge then is to maintain biodiversity, protect ecosystems and manage the sustainable extraction of these resources. With this being such a vast topic, I have chosen to focus here on the challenge of the lack of data on our ability to assess and prioritize marine species or ecosystems.

Although a recent study of the scientific literature by Borja (2014), illustrates the dramatic increase in the number of articles including the words "marine ecosystems" (in the abstract, title, or keywords) over the past decade, and a similar rise is seen if we repeat the above exercise with "marine conservation" as the search term, several studies have highlighted the lack of marine conservation articles in both general conservation and aquatic focused journals (Levin and Kochin, 2004; Hendriks et al., 2006; Parsons, 2014), particularly those of high impact. Whether this is a result of the difficulty and additional expense of working in the marine environment, a lack of perceived interest by those working in terrestrial systems, or a lack of available funding is a matter of debate (Norse and Crowder, 2005; Richardson and Poloczanska, 2008), but recent data from the IUCN would suggest that lack of data is a major issue for accurate species and habitat assessments (IUCN, 2014). If we don't know the status of a species or ecosystem, how can we assess the impact of a threat?

As the IUCN celebrates 50 years of the Red List of Threatened Species, it has a goal to more than double the number of species assessed from 76,199 (IUCN, 2014) to over 160,000 by 2020 . This is still less than $10 \%$ of described species and highlights the need to acquire data for key species assessments. In particular, there is a need to focus on the marine environment, making up fewer than 13\% (9608 species) of assessed species, with $69 \%$ being terrestrial $(52,602)$ and $34 \%(25,785)$ freshwater species. Although $29 \%$ of all assessed species are listed in the threatened categories [Critically Endangered (CR), Endangered (E) and Vulnerable (V)], in the marine realm only $11 \%$ of assessed species are listed as threatened. A closer look at the data however, shows that $25 \%$ of all marine species assessed are listed as Data Deficient (DD, meaning insufficient data to make an accurate assessment), in comparison to $12 \%$ of terrestrial species (and 17\% of all species assessed). These
DD species need to remain a priority and be treated as if they were in the threatened categories until data are available for accurate classification (McCauley et al., 2015; Parsons et al., in press), this is particularly important for long-lived species that need decades of monitoring before accurate assessments can be made.

Of the marine species that are currently included on the IUCN Red List there is a clear bias toward vertebrates, making up $68 \%$ of those assessed, with $30 \%$ invertebrates and only $2 \%$ plants (Schipper et al., 2008; Polidoro et al., 2009; IUCN, 2014). A similar bias is, not surprisingly, seen in the scientific literature, toward marine megavertebrates and coastal habitats and ecosystems (McClenachan et al., 2012), both easier to assess (especially air breathers and those that haul out or breed on land) and potentially more likely to gain conservation support and funding. Species that haul out or breed on land have also however, been shown to have a greater risk of becoming threatened (McCauley et al., 2015). Given that we are unlikely to ever have all the data we want to make informed management decisions it is often necessary to focus efforts on gathering data on species that are considered to be indicative of the state of an ecosystem (Maxwell et al., 2013) or on social science studies to help to prioritize our efforts (Maxwell et al., 2014).

Adapting the existing IUCN Red List species criteria to assess marine ecosystems, Jackson (2008) has suggested that Coral Reefs and Estuaries and Coastal Seas should be listed as the most critically endangered marine ecosystems. Perhaps it is no surprise that the status of ocean ecosystems (Jackson, 2008) reduces with 
distance from major land mass and the influence of anthropogenic activities, but as we develop more advanced technologies to exploit the oceans, it is likely that the threat status of pelagic and deep sea habitats will also increase. It is pleasing to note that the IUCN is currently developing Red List criteria for the assessment of ecosystems (Keith et al., 2013), although there has been some criticism regarding the difficulty of classification of ecosystems (Boitani et al., 2014).

Accurate species or ecosystem assessment also requires a greater understanding of the impact that stressors may have, but many studies focus on single species or single stressors and fail to consider the synergistic effects. Several recent studies have highlighted the need to understand the cumulative effect that multiple stressors have on species or species groups, how these vary spatially (Maxwell et al., 2013), and at what level they have a critical impact at a population level (Davidson et al., 2012).

Owing in part to the Aichi Biodiversity Targets of the Convention on Biological Diversity (CBD) for countries to protect $10 \%$ of coastal and marine areas by 2020, we have recently seen an increase in the designation of large-scale marine protected areas (LSMPAs) that now make up $80 \%$ of MPAs world-wide (Leenhardt et al., 2013) and more recently the USA has proposed an expansion of the Pacific Remote Islands Marine National Monument that would make this one of, if not the, largest MPAs in the world. There has been some debate regarding the rise in LSMPAs (Leenhardt et al., 2013; Wilhelm et al., 2014), with suggestions that these are not priority areas for protection, but the easiest fix to achieving targets, being placed in areas that are uninhabited by humans, and where stakeholder consultation is limited or not required. There is a need to ensure that the most important and at risk ecosystems are being protected and a Red List of threatened ecosystems could prove an important tool for prioritization of areas by decision makers.

Perhaps however, our greatest challenges are those that exist in the Areas Beyond National Jurisdiction (ABNJ), where management is reliant on international agreements and enforcement is likely to need remote monitoring methods using satellite technologies. Even within Exclusive Economic Zones (EEZs), enforcement of Illegal Unregulated Fisheries (IUF) is a major issue, requiring expensive boat or aerial enforcement and many countries are already looking to remote monitoring methods. Dynamic ocean management (Hobday et al., 2014) may become more common as a management tool that provides flexibility in time and space in how we utilize the oceans resources and how we manage these large MPAs (Maxwell et al., 2014).

For some species however, we are now seeing a recovery (Lotze et al., 2006) and down-listing from the threatened categories of the IUCN Red List, a cause for celebration, but which some find a cause for concern. A good example of this is my own area of research, the green turtle (Chelonia mydas), currently (IUCN, 2014) listed as globally endangered, many nesting populations have dramatically recovered over the past two decades, most notable are the large colonies nesting at Ascension Island, Costa Rica and Hawaii (Chaloupka et al., 2008; Weber et al., 2014). It is highly probably that we will see this species removed from the threatened categories when the next assessment is completed. Although many legal marine turtle fisheries currently operate (Humber et al., 2014), with over 40,000 green turtles (90\% of catch) estimated to be legally captured each year, illegal fisheries remain unquantified and likely exceed this. Yet at sites where humans have reduced other marine species through exploitation at unsustainable levels, and green turtles appear plentiful, even to a level that they may be damaging the ecosystem (Heithaus et al., 2014), it is difficult not to consider allowing this species to be fished, although to ensure sustainability could be a major challenge. Having worked in countries where stocks of conch and lobster have been massively depleted, turtles are plentiful, and the alternatives for fishers are reef fish, the sustainable use of marine turtles needs to be seriously considered.

There are indeed grand challenges for marine conservation. Some, such as reduction of the threats posed by fisheries, seem potentially achievable, if challenging, others, such as the impacts of climate change, seem overwhelming huge and our best efforts are likely to be in understanding and mitigation of threats. It is clear that in order to reduce and mitigate the impact of threats on marine biodiversity we need a greater understanding of their effects on the species and ecosystems on which they act. The recently published article-Seventy-one important questions for the conservation of marine biodiversity (Parsons et al., 2014) demonstrates the breadth and complexity of issues in this field, which range from understanding the direct and indirect impacts of fisheries and climate change to societal and cultural considerations. Answering these 71 questions would indeed be a great start!

As scientists however, we do need to question whether we are making the most of our data, whether we are sharing it with policy and decision makers in a form that is comprehensive for their needs, and how we can encourage them to use these data to inform decisions. Having the data is only one step toward the conservation and sustainable use of marine species and habitats.

\section{REFERENCES}

Boitani, L., Mace, G. M., and Rondinini, C. (2014). Challenging the scientific foundations for an IUCN Red list of ecosystems. Conserv. Lett. doi: 10.1111/conl.12111. [Epub ahead of print].

Borja, A. (2014). Grand challenges in marine ecosystems ecology. Front. Mar. Sci. 1, 1-6. doi: 10.3389/fmars.2014.00001

Butchart, S. H. M., Walpole, M., Collen, B., vanStrien, A., Scharleman, J. P. W., Almond, R. E. A., et al. (2010). Global biodiversity: indicators of recent declines. Science 328, 1164-1168. doi: 10.1126/science. 1187512

Chaloupka, M., Bjorndal, K. A., Balazs, G. H., Bolten, A. B., Ehrhart, L. M., Limpus, C. J., et al. (2008). Encouraging outlook for recovery of a once severely exploited marine megaherbivore. Glob. Ecol. Biogeogr. 17, 297-304. doi: 10.1111/j.14668238.2007.00367.x

Davidson, A. D., Boyer, A. G., Kim, H., PompaMansilla, S., Hamilton, M. J., and Costa, D. P., et al. (2012). Drivers and hotspots of extinction risk in marine mammals. Proc. Natl. Acad. Sci. U.S.A. 109 3395-3400. doi: 10.1073/pnas.1121469109

Dulvy, N. K., Fowler, S. L., Musick, J. A., Cavanagh, R. D., Kyne, P. M., Harrison, L. R., et al. (2014). Extinction risk and conservation of the world's sharks and rays. eLife 3:e00590. doi: 10.7554/eLife. 00590

Halpern, B. S., Walbridge, S., Selkoe, K. A., Kappel, C. V., Micheli, F., D’Agrosa, C.,et al. (2008). A global map of human impact on marine ecosystems. Science 319, 948-952. doi: 10.1126/science. 1149345

Heithaus, M. R., Alcoverro, T., Arthur, R., Burkholder, D. A., Coates, K. A., Christianen, M. J. A., et al. (2014). Seagrasses in the age of sea turtle 
conservation and shark overfishing. Front. Mar. Sci. 1:28. doi: 10.3389/fmars.2014.00028

Hendriks, I. E., Duarte, C. M., and Heip, C. H. R. (2006). Biodiversity research still grounded. Science 312, 1715. doi: 10.1126/science. 1128548

Hobday, A. J., Maxwell, S. M., Forgie, J., McDonald, J., Darby, M., Seto, K., et al. (2014). Dynamic ocean management: integrating scientific and technological capacity with law, policy and management. Stanford Environ. Law J. 33, 125-168.

Humber, F., Godley, B. J., and Broderick, A. C. (2014). So excellent a fishe: a global overview of legal marine turtle fisheries. Divers. Distrib. 20, 579-590. doi: 10.1111/ddi.12183

IUCN (2014).The IUCN Red List of Threatened Species. Version 2014.3. Available online at: http://www.iucnredlist.org (Accessed November $17,2014)$.

Jackson, J. B. (2008). Ecological extinction and evolution in the brave new ocean. Proc. Nat. Acad. Sci. U.S.A. 105, 11458-11465. doi: 10.1073/pnas.0802812105

Keith, D. A., Rodríguez, J. P., Rodríguez-Clark, K. M., Nicholson, E., Aapala, K., Alonso, A., et al. (2013). Scientific foundations for an IUCN Red list of ecosystems. PLoS ONE 8:e62111. doi: 10.1371/journal.pone.0062111

Leenhardt, P., Cazalet, B., Salvat, B., Claudet, J., and Feral, F. (2013). The rise of large-scale marine protected areas: conservation or geopolitics? Ocean Coast. Manag. 85, 112-118. doi: 10.1016/j.ocecoaman.2013.08.013

Levin, P. S., and Kochin, B. F. (2004). Publication of marine conservation papers: is conservation biology too dry? Conserv. Biol. 18, 1160-1162. doi: 10.1111/j.1523-1739.2004.00452.x

Lotze, H. K., Lenihan, H. S., Bourque, B. J., Bradbury, R. H., Cooke, R. G., Kay, M. C., et al. (2006). Depletion, degradation, and recovery potential of estuaries and coastal seas. Science 312, 1806-1809. doi: 10.1126/science. 1128035

Maxwell, S. M., Ban, N. C., and Morgan, L. E. (2014). Pragmatic approaches for effective management of pelagic marine protected areas. Endang. Species Res. 26, 59-74. doi: 10.3354/esr00617
Maxwell, S. M., Hazen, E. L., Bograd, S. J., Halpern, B. S., Breed, G. A., Nickel, B., et al. (2013). Cumulative human impacts on marine predators. Nat. Commun. 4:2688. doi: 10.1038/ncomms3688

McCauley, D. J., Pinsky, M. L., Palumbi, S. R., Estes, J. A., Joyce, F. H., and Warner, R. R. (2015). Marine defaunation: animal loss in the global ocean. Science 347:1255641. doi: 10.1126/science.1255641

McClenachan, L., Cooper, A. B., Carpenter, K. E. and Dulvy, N. K. (2012). Extinction risk and bottlenecks in the conservation of charismatic marine species. Conserv. Lett. 5, 73-80. doi: 10.1111/j.1755-263X.2011.00206.x

Neubauer, P., Jensen, O. P., Hutchings, J. A., and Baum, J. K. (2013). Resilience and recovery of overexploited marine populations. Science 340 , 347-349. doi: 10.1126/science.1230441

Norse, E., and Crowder, L. B. (2005). "Why marine conservation biology?" in Marine Conservation Biology, eds E. Norse and L. B. Crowder (Washington, DC: Island Press), 1-18.

Parsons, E. C. M. (2014). No You're Not Paranoid - There is a Bias Against Publishing Marine Conservation Papers. Southern Fried Science. Available online at: www.southernfriedscience. $\mathrm{com} / \mathrm{?} \mathrm{p}=17746$

Parsons, E. C. M., Baulch, S., Bechshoft, T., Bellazzi G., Bouchet, P., Cosentino A. M., et al. (in press). Key research questions of global importance for cetacean conservation. Endang. Species Res.

Parsons, E. C. M., Favaro, B., Alonso Aguirre, A., Bauer, A. L., Blight, L. K., Ciglinao, J. A., et al. (2014). Seventy-one important questions for the conservation of marine biodiversity. Conserv. Biol. 28, 1206-1214. doi: 10.1111/ cobi. 12303

Polidoro, B. A., Livingstone, S. R., Carpenter, K. E., Hutchinson, B., Mast, R. B., Pilcher, N. J., et al. (2009). "Status of the world's marine species," in Wildlife in a Changing World-An Analysis of the 2008 IUCN Red List of Threatened Species (Iucn; Gland), 55.

Richardson, A. J., and Poloczanska, E. S. (2008). Under-resourced, under threat. Science 320, 1294-1295. doi: 10.1126/science.1156129
Schipper, J., Chanson, J. S., Chiozza, F., Cox, N. A., Hoffmann, M., Katariya, V., et al. (2008). The status of the world's land and marine mammals: diversity, threat, and knowledge. Science 322, 225-230. doi: 10.1126/science. 1165115

Selig, E. R., Turner, W. R., Troëng, S., Wallace, B. P., Halpern, B. S., Kaschner, K., et al. (2014). Global priorities for marine biodiversity conservation. PLOS ONE 9:e82898. doi: 10.1371/journal.pone.0082898

Weber, S., Weber, N., Ellick, J., Avery, A., Frauenstein, R., Godley, B. J., et al. (2014). Recovery of the South Atlantic's largest green turtle nesting population. Biodivers. Conserv. 23, 3005-3018. doi: 10.1007/s10531-014-0759-6

Wilhelm, T. A., Sheppard, C. R. C., Sheppard, A. L. S. Gaymer, C. F., Parks, J., Wagner, D., et al. (2014). Large marine protected areas - advantages and challenges of going big. Aquat. Conserv. 24, 24-30. doi: $10.1002 /$ aqc. 2499

Conflict of Interest Statement: The author declares that the research was conducted in the absence of any commercial or financial relationships that could be construed as a potential conflict of interest.

Received: 11 December 2014; accepted: 05 February 2015; published online: 19 February 2015.

Citation: Broderick AC (2015) Grand challenges in marine conservation and sustainable use. Front. Mar. Sci. 2:11. doi: 10.3389/fmars.2015.00011

This article was submitted to Marine Conservation and Sustainability, a section of the journal Frontiers in Marine Science.

Copyright (c) 2015 Broderick. This is an open-access article distributed under the terms of the Creative Commons Attribution License (CC BY). The use, distribution or reproduction in other forums is permitted, provided the original author(s) or licensor are credited and that the original publication in this journal is cited, in accordance with accepted academic practice. No use, distribution or reproduction is permitted which does not comply with these terms. 